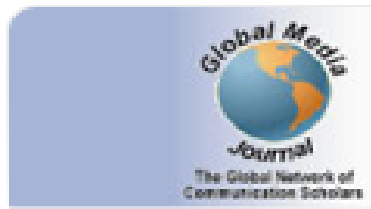

Global Media Journal

ISSN: 2007-2031

globalmedia_enespanol@hotmail.com

Instituto Tecnológico y de Estudios

Superiores de Monterrey

México

Sandoval-Almazan, Rodrigo; Valle-Cruz, David

ONLINE ACTIVITIES THROUGH SOCIAL MEDIA BY HIGH EDUCATION STUDENTS:

BUSINESS VS. INFORMATICS

Global Media Journal, vol. 13, núm. 25, 2016, pp. 42-62

Instituto Tecnológico y de Estudios Superiores de Monterrey

Monterrey, México

Available in: http://www.redalyc.org/articulo.oa?id=68748631003

- How to cite

- Complete issue

More information about this article

Journal's homepage in redalyc.org



Scientific Information System Network of Scientific Journals from Latin America, the Caribbean, Spain and Portugal Non-profit academic project, developed under the open access initiative 


\title{
ONLINE ACTIVITIES THROUGH SOCIAL MEDIA BY HIGH EDUCATION STUDENTS: BUSINESS VS. INFORMATICS
}

\author{
Rodrigo Sandoval-Almazan ${ }^{* 1}$ \\ David Valle-Cruz ${ }^{2}$ \\ Autonomous University of the State of Mexico
}

\begin{abstract}
Online Social Networks (OSN) are the new tools that students are using to interact, communicate and collaborate for school work. The impact on school activities, as well as the communication mechanisms among students, have just started to be studied. This research focuses on this issue, trying to answer the question: How do college students use OSN to improve communication and exchange knowledge? For this purpose we used the application of two online surveys applied to students of business administration (BBA - Bachelor in Business Administration) and informatics management (BIM - Bachelor in Informatics Management) students in 2010 and 2012 in Mexico. Our findings reveal that business administration students are the ones that use these kinds of platforms more frequently for sharing information and communicating with their peers. The comparison of these two surveys shows how the behavior and activities among students have changed.
\end{abstract}

Keywords: education, Internet, students, OSN, online social media, Twitter, Facebook 
Introduction

The use of social network sites (SNS) such as Facebook, Twitter, LinkedIn, Pinterest, Google Plus+, Tumblr, and Instagram, among others, has increased at a very fast pace in the last few years (Di Valentin et al., 2014; Lenartz, 2012; Teoh, Pourshafie, \& Balakrishnan, 2014). With the advancement of information, communication and technologies (ICTs), especially in mobile technology, various SNS rapidly developed in the past decade (Au, Lam, \& Chan, 2014).

The incorporation of mobile devices and social media content into everyday life has radically changed the acquisition of information, as well as the reading and learning mechanisms (Molnar \& Szuts, 2014). Given the ubiquity of social media and the high rate of social media utilization among college students, it's not surprising then that educators are turning to social media as a platform and tool for meeting educational objectives (Kamal et al., 2013; Tuten, Wetsch, \& Munoz, 2015). As a consequence, part of the users today require a rapid acquisition of knowledge.

On the other hand, interaction between teachers and students has experimented different formal and informal ways in classroom teaching (Au et al., 2014; Tuten et al., 2015). SNS's popularity with students makes it a very useful tool to exploit for classroom teaching and management (Lenartz, 2012; Teoh et al., 2014). So, the use of social media gives several advantages to both students and teachers; for example: it makes studying processes transparent, offers both peer encouragement and peer discipline, and enhances students' competence in ICTs (Kilpeläinen, Päykkönen, \& Sankala, 2011).

Recently students have become digital natives, according to Tapscott (2009) who has suggested this category for those who were born after the Internet marketing. These digital natives who now walk through the university and high school classrooms have increased. In Mexico, young people (15 - 29 years old) represent half of the population, from which over 29 million are younger than 26 years, 15 million are women and 14 million are men. These young people are usually relatively well educated, $23 \%$ have college studies, $20 \%$ are in college and $1.2 \%$ are enrolled in master's degree studies. From this number, only 47\% are employees (INEGI, 2011). More than $30 \%$ use Internet from home.

The introduction of mobile- and smartphones has changed the face of communications in Mexico and therefore has impacted the communication of younger people. Internet penetration in Mexico has grown 13\% from 2013 to 2014.

Currently there are 95 million cell lines in Mexico, where 4 out of 5 Mexicans have a digital line and the company Telcel has 68 million users (Cruz, 2011); on the side of social media, Facebook (FB) and Twitter adoption (2012), as shown in Table 1.

TABLE 1. SOCIAL NETWORKS IN MEXICO. 


\begin{tabular}{|c|c|c|c|c|}
\hline & $\begin{array}{c}\text { Internet }^{1} \\
(2014)\end{array}$ & $\begin{array}{c}\text { Facebook (FB) } \\
(2015)\end{array}$ & $\begin{array}{c}\text { Twitter } \\
(2014)\end{array}$ & $\begin{array}{c}\text { Cell Phone } \\
(2014)\end{array}$ \\
\hline Mexico & 51.2 Millions & 55.3 Millions & 24.8 Millions & 95 million cell lines \\
\hline
\end{tabular}

SOURCE (AMIPCI, 2012)

\footnotetext{
${ }^{1}$ Source: Mexican Association of Internet (AMIPCI, 2014) December 2014
}

Global Media Journal Mexico, Vol. 13, No. 25 Pp. 42-62. 
Every day around 28 million Mexicans connect to Internet, 9 out of every 10 users have an account in Facebook and 6 out of 10 have Twitter accounts (AMIPCI, 2014). Despite this progress, the digital divide between those who have Internet access and those who doesn't (51 million) (AMIPCI 2014) begins to define their educational possibilities, employment alternatives and professionalization.

Researchers such as Bauerlein (2009) and Nicholas Carr (2011) believe that the use of Internet and social networks is damaging students and making them slower in their thinking and less active in their mental processes because of spending too many hours "being programmed" through the social platforms and the Google oracle.

These concerns increased our interest and we started this research, asking the following questions: How much impact do social networks have on college education? Are these statements from researchers and journalists real? Does the Mexican case have the same characteristics as the rest of the world? Particularly, for this research, we studied the question: How do High Education Students of Business and Informatics use social networks to improve communication and exchange knowledge?

We decided to implement an exploratory study in 2010 among our students at the Autonomous University of the State of Mexico that would generate some ideas and allow us to assess our measuring instrument for such a new phenomenon as the use of OSN among students. Later, we repeated the study in 2012. We added some questions and new observations to the instrument as a result of the previously acquired experience. This article only shows the comparison between some questions asked in the first survey and the last measurement.

This article is divided into five sections. The first one is an introduction to the context and the described issue; the second section reviews the related literature to the topic of communication among students using social networks; the third section describes our methodology when analyzing students in the years 2010 and 2012; the fourth section shows the findings; and the fifth and last one shows some conclusions and future research lines.

\section{Literature Review}

The purpose of this literature review is to explore the main research on three areas: 1 . College students and their use of online social networks; 2. Online social networks and its use in education; and 3. Previous research about Twitter and Facebook platforms related to college students and OSN.

\section{College students and their use of online social networks}

Under the educational approach of the electronic social networks, Richardson \& Hessey (2009) started interviewing 11,000 teenagers in USA in order to understand this "network" generation and discovered new ways of thinking, interacting, working and socializing. Their work reveals how this new generation processes information and is committed to 
establish joint actions. This is a pioneering work that illustrates how the use of different social networks and platforms is interrelated.

In another similar study, 700 teenagers in public schools were analyzed, trying to foresee whether social inequality, gender, ethnicity, socioeconomic status, self-esteem, etc., had an impact on how they behave online using social networks such as Facebook and MySpace. The results indicated that there was a digital divide according to the criteria of social inequality offline - or physical - in contrast to the activity using social networks (J. Ahn, 2011). Following this line of research, Bauerlein's book (2011) contains a number of texts, essays and research related to the digital divide against the use of Facebook, Google and text messages, where several authors, as well as the same Tapscott analyzes the challenges and difficulties of accessing these new technologies under the gaze of adolescents.

Other researches have focused more on general issues such as the use of social networks and their impact on learning (Greenhow, 2011) or focused on getting to understand issues such as trust (Jessen \& Jørgensen, 2011); acceptance in the use of these new technologies (Pinho \& Soares, 2011) and their use by sociodemographic variables (Ruleman, 2012) or ethnographic studies (Murthy, 2013).

An interesting research by Rajagopal, Brinke, Bruggen, \& Sloep (2011) presents a model for creating a personal learning network, using social networks as a result of a series of semi-structured interviews with both professionals and university students.

Ahn's research (2011) analyzes a data set of 701 U.S. teenagers (ages 12-18) that merges an online survey of social network site (SNS) preferences with administrative records from their public school districts. She examines offline divides across gender, ethnicity, socioeconomic status, self-esteem and social capital predicting teenagers' membership to Facebook and MySpace. Her findings offer two main contributions by providing an analysis of: (a) teenage SNS users, a population that is less examined in the research literature of online communities; and, (b) the relationship between their off-line characteristics and online social networks.

On the other hand, Theocharis (2012) studied the role of a variety of online tools and methods that were used to coordinate and mobilize young people after the UK riots. The study revealed the extensive use of old and new online platforms and hardware, and the constant blending of offline and online repertoires of participation. Fardoun, Zafar, \& Ciprés (2013) analyzed features and differences between Facebook and Learning Management System (LMS) in educational activities.

Burkell, Fortier, Wong, \& Simpson (2014) focused their research on Facebook as a public or private space. They found that online social spaces are indeed local spaces of public display rather than a private revelation: online profiles are structured with the view that 'everyone' can see them, even if the explicitly 
intended audience is more limited. These social norms are inconsistent with the claim that social media are private spaces.

A complete research from Nicolle Merrill (2011) shows how social media tools such as Facebook and Twitter are increasingly being integrated into recruiting and outreach activities throughout US universities. Using an exploratory online survey, distributed through online social networks, the author gathers data about the use of social media in international higher education, recruiting and outside activities, gaining insight into the norms, rules and workings of social networking communities. Her findings pointed to new methods for understanding the evolution of higher education communications for researchers and university staff alike.

This study presents and tests new methods for conducting research in higher education communications. The author presents digital ethnography as a relevant methodological approach for researching and understanding online communities in higher education. The exploratory survey sought information about which social media tools were being used by university staff, the perceived benefits and drawbacks of social media use in international recruiting and outreach activities, and how universities measured social media for international recruiting purposes using a digital ethnographic approach.

\section{Online Social Networks and Education}

Global Media Journal Mexico, Vol. 13, No. 25 Pp. 42-62.
Online social networks research has to be divided into two different moments: before and after Internet. The first stage - before Internet - shows that social networks started to be studied since the XVIII century and that its conceptualization comes from Durkheim and Ferdinand Tonnies. Afterwards, in the XIX century, it was Simmel - according to Freeman (2004) - who used the concept "social networks" for the first time. From that time on, many schools were devoted to investigate the impact of social networks in organizations, businesses, schools and social movements (Freeman, 2004).

The second stage began when social networks started to use technology and they are now called Online Social Networks (OSN) Haythornthwaite (2005). This is the result of an evolutionary process of social organization in which groups of individuals are connected to coordinate and act together.

Research about online social networks has experienced a boom during the last decade. Katz, Lazer, Arrow, \& Contractor (2004) were the first ones to analyze the network theory and social groups with the use of technology. Kavanaugh et al. (2006) analyzed one of the first blogging tools to exchange information, solve problems and interact with groups. Their analysis of opinion-leaders' is one of the first serious studies on the impact of these new tools and their interaction with citizens.

One of the preliminary researches on privacy in OSN was made by Krishnamurthy \& Wills (2008). This field has become tremendously important nowadays. 
Following this topic of research, Marwick \& boyd (2014) studied about teenagers and privacy. They argue that the dynamics of sites such as Facebook have forced teens to alter their conceptions of privacy to account for the networked nature of social media. From this perspective, these scholars developed a model of networked privacy to explain how privacy is achieved in networked publics.

Chung \& Chatfield (2011) examines the role of online social network structure as a mechanism for facilitating collaborative civic engagement. Indrupati $\&$ Henari's research (2012) focuses on entrepreneurial success using OSN. They found that social networking is a cheap and easy method of advertising and giving all entrepreneurs a better chance of reaching their target market. Another online social network research is business impact. For example, Swamynathan, Wilson, Boe, Almeroth, \& Zhao (2008) has been researching about e-commerce impact and social media with data from 400,000 overstock users.

\section{Twitter, Facebook \& College Students}

There are several scholars that have been studying social media in education. Junco (2008) analyzed the introduction of technologies for college students; Lampe, Ellison, \& Steinfield (2006) analyzed students using Facebook. Ellison, Steinfield, \& Lampe (2007) demonstrated the benefits of Facebook through social capital. Another example comes from Isacsson \& Gretzel (2011) who presented the idea that a platform has to be an entertaining educator in order to attract students' attention and to transmit knowledge. Loving
\& Ochoa (2011) gave another approach about using the platform as a tool to manage a course while encouraging greater interaction between students and teachers. In this sense, Aharony (2012, 2013) performed studies in Israel on th@e impact of Facebook being used in libraries and how it influenced students' perception, personalities, self-esteem and interaction features.

A very recent study showed changes in the preferences of international students compared to "local" students. They were analyzed through Facebook and showed differences in both, collaboration and teamwork (Saw, Abbott, Donaghey, \& McDonald, 2013). Another similar study found that different levels of Facebook use - more or less use - was linked to various schoolrelated attitudes. For example, a greater use was associated to a negative attitude in school and this had a greater impact among women (Koles \& Nagy, 2012).

One of the few theoretical models for analyzing the impact of Facebook on students is the one developed by Koroleva, Brecht, Goebel, \& Malinova (2011), which needs to be tested with more students, because they only worked with a small sample of less than 10 students. This model can become an important tool to study the impact.

There are different studies regarding Facebook. Some are less related to education as highlighted by Ellison, Steinfield, \& Lampe (2007) who compared the "social search" and the "social navigation of the network"; or Hargittai's investigations (2007) on non-social network users as a public space and its impact on privacy 
(Boyd \& Hargittai, 2010). Also, the use of Facebook as a promoter of negative groups has also been studied by Oboler (2008).

(Wang, Niiya, Mark, Reich, \& Warschauer, 2015) conducted a mixed-method study of computer and phone logging with daily surveys and interviews to track college students' use of social media during all waking hours during seven days. They found age differences: younger students tend to be heavier users and they use different sites more often than Facebook. Their results suggest that students construct their own patterns of social media usage to meet their changing needs in their environment. Also there are very few studies which look into the effect of gender on the use of SNS in education (Teoh et al., 2014).

However, guidelines and policies describing the institutions' strategy and expectations for the use of social media are being utilized at a much lower rate than the use of social media itself. This has the potential to reduce the effectiveness of social media by institutions of higher education and to create a barrier in the use of social media before the benefits can even be fully realized (Lenartz, 2012). Regardless of the popularity of social media, the effectiveness of using existing social media tools to facilitate teaching and learning is not noticeable (Au et al., 2014).

Social Media has infiltrated in different ways among users, and none more than the current digital native who is studying at university. This has led to the rise in questions of how best to use these computer-mediated communications in academic settings (Danino \& Sim, 2014).

Another problem is that the training of social media skills is not yet sufficiently integrated into the processes of vocational education (Di Valentin et al., 2014). Moreover understanding why some users adopt or reject any technology is a difficult question to answer. Nirban \& Chasul (2014) used the Unified Theory of Acceptance and the Use of Technology to understand the students' acceptance of a Learning Management System.

A very important consequence is that the information boom has radically altered the teachers' roles. Teachers can no longer be a source of information, but are now meant to provide methodological assistance to students. So the new type of teaching-learning can be addressed as connectivism and connective knowledge, which is adapted to 21 st century man dynamic way of life (Molnar \& Szuts, 2014). This way, communication among students and between students and teacher has changed, such as knowledge sharing. Thus, one important question to answer is the use of advanced mobile communication services and applications in the base of higher education (Molnar \& Szuts, 2014).

Particularly, in developing countries, social media not only satisfies personal communication needs, but also tends to compete with mainstream media for news and play a significant role in social movements. Hence potential use of this mounting medium for education needs to be explored (Celik \& Schoreels, 2014). 
Thus the objective of this research is to answer the particular question: How do college students use social networks to improve communication and exchange knowledge? We will explore some factors of this new trend of connectivism and connective knowledge in the use of Social Networks by high education students.

\section{Methodology}

Research from Estalella \& Ardevol (2011) on Internet studies states that this is a new field that requires a different approach because of the conditions in which it is generated: a very fast changing field of study where it is not possible to do research in a typical and traditional way, as used for natural or exact sciences (Galliers \& Myers M, 2002).

Internet research has to be done in socioeconomic and cultural heterogeneous structures - such as municipalities, urban or rural, state and federal offices, etc., which causes several problems in the design and implementation of the study (Gallupe, 2007). Finally, we must say that the information system is an applied science; it is not a pure science. Therefore, in order to use the same methods used for pure sciences would not provide optimal results (Boudreau, 2001; Galliers \& Myers M, 2002). These reasons distinguish the Internet research from a qualitative or quantitative method.

The focus of this study is to use quantitative descriptive methods. According to (Hernández Sampieri, Fernandez Collado, \& Baptista Lucio (2010) a descriptive study is a second stage that supports a correlational research and seeks for specific properties, features and profiles of groups, people or objects. They measure, assess or collect data about several variables with the intention of describing what is being searched.

This implies to find evidence in order to establish concepts, research areas and even that we can suggest some explanations to help building a theory (Hakim, 1987). Being a descriptive study, there is no hypothesis for this paper. However, there is a question that will lead this study: How do high education student of Business and Informatics use social networks in order to improve communication and exchange knowledge?

Based on the literature review we developed a questionnaire of 27 questions. We only present 9 questions in this study because we consider them the most relevant ones in order to show the change in the interaction of communication and knowledge sharing. The questionnaire was tested with a pilot test in 2010 and some questions were added in 2012. The questions for comparison purposes were not changed. The data collection was performed during November and December, 2010 and in December and January, 2012. We used the online system called Survey Monkey.

The sample consists of students of the Business' School at the Autonomous University of the State of Mexico. In this school there are students of Management, Accounting, Marketing, and Informatics. Management, Accounting, and Marketing are Business' students. But Informatics' students are 
specialist in the use of technology. So we classified into this two groups in order to compare them.

Furthermore our sample was divided into two parts: the students interviewed in 2010 and the interviewed ones in 2012. Table 2 shows the composition and the number of valid cases. Respondents were 52\% males and $48 \%$ females in both years. For both measurements, the questionnaire was sent by email and students were asked to answer on line. Although more than 100 emails were sent for each type of student (business and informatics) per year (400 mails), the response rate was less than $56 \%$. Personal data was never requested.

TABLE 2. SAMPLE DATA

\begin{tabular}{|l|c|c|}
\hline & $\begin{array}{c}\text { Business } \\
\text { Administration } \\
\text { BBA }\end{array}$ & $\begin{array}{c}\text { Informatics } \\
\text { Management } \\
\text { BIM }\end{array}$ \\
\hline Measurement 2010 & 58 & 68 \\
\hline Measurement 2012 & 48 & 53 \\
\hline
\end{tabular}

Findings

In order to present the findings, we divided them accordingly to each of the questions asked in the survey. There are several things that stand out in the first question regarding the use of different social media platforms. In 2010 both types of students, business administration and informatics management have their computers switched on when doing a research project for school. Even though, in 2012 the number of BBA's falls dramatically but the use of cellphones increases.

TABLE 3. QUESTION 1 CONNECTION AND SOCIAL NETWORK

\begin{tabular}{|l|l|l|l|l|}
\hline Answer Options & BBA & BIM & BBA & BIM \\
& 2010 & 2010 & 2012 & 2012 \\
\hline Computer & $42.6 \%$ & $48.5 \%$ & $27.6 \%$ & $49.1 \%$ \\
\hline Social networks (Twitter, Facebook, MetroFLOG) & $13.0 \%$ & $10.3 \%$ & $34.5 \%$ & $13.2 \%$ \\
\hline Cellphone & $25.9 \%$ & $30.9 \%$ & $31.0 \%$ & $24.5 \%$ \\
\hline All of these & $53.7 \%$ & $50.0 \%$ & $55.2 \%$ & $52.8 \%$ \\
\hline None of these & $1.9 \%$ & $1.5 \%$ & $0.0 \%$ & $0.0 \%$ \\
\hline
\end{tabular}


Another point is the social networks. In 2010, less than $15 \%$ had social networks turned on. In 2012, this \% increased and in the case of the BBA's, it increased three times, reaching a $34 \%$ of the cases. However, cellphone use among students has not changed drastically while doing school tasks. According to the responses of all the above, there is only a slight increase with the BBA's in 2012.

The second question seeks the kind of social networks that students use (see Table 4). Migration from Hi5, MySpace and MetroFLOG - still in 2010 - to Facebook and Twitter is clearly shown. The last one has still less than $50 \%$ of the students as new users. It is clear that students have been migrating their interactions to the new two platforms. The survey held in 2012 showed that from the total sample all of BBA's students and the $88.46 \%$ of BIM's students used Facebook. For this year, only $42.86 \%$ of the BBA's students used Twitter and 46.15 of BIM's students used Twitter too. The $61.54 \%$ of the BIM's students and the $42.86 \%$ of BBA's students used YouTube.
During 2010, $82.35 \%$ of BBA's students and $86.15 \%$ of BIM's students used Facebook. The use of Twitter was very low, BBA's students with $15.69 \%$ and BIM's students $20.00 \%$.

The third question is linked to the previous one and refers directly to the sharing of knowledge. It was directly asked if they had found friends to do "school tasks or school jobs". In this sense, the lack of use of MetroFLOG, Hi5, Sonico and MySpace as the networks for finding friends is clear. In the case of BIM students, they find more friends on Twitter and Facebook - increasing $8 \%$ - between both measured years. On the contrary, BBA students moved more towards Twitter, increasing almost 3 times from 7.8 to $24 \%$ and found more friends on Facebook. This may be due to a natural migration between them, which was explained in the previous question. Finally, it is interesting to observe how the use of other social networks has reduced - see the last option on the Table 4 - and has focused more on Facebook and Twitter.

TABLE 4. SOCIAL NETWORKS COMPARISON

\begin{tabular}{|l|l|l|l|l|}
\hline Answer Options & $\begin{array}{l}\text { BBA } \\
2010\end{array}$ & $\begin{array}{l}\text { BIM } \\
2010\end{array}$ & $\begin{array}{l}\text { BBA } \\
2012\end{array}$ & $\begin{array}{l}\text { BIM } \\
2012\end{array}$ \\
\hline MetroFLOG & $2.0 \%$ & $1.5 \%$ & $0.0 \%$ & $0.0 \%$ \\
\hline Hi5 & $3.9 \%$ & $4.6 \%$ & $0.0 \%$ & $1.9 \%$ \\
\hline Facebook & $82.4 \%$ & $86.2 \%$ & $100.0 \%$ & $88.5 \%$ \\
\hline Twitter & $15.7 \%$ & $20.0 \%$ & $42.9 \%$ & $46.2 \%$ \\
\hline MySpace & $3.9 \%$ & $0.0 \%$ & $0.0 \%$ & $1.9 \%$ \\
\hline Sonico & $2.0 \%$ & $0.0 \%$ & $0.0 \%$ & $0.0 \%$ \\
\hline
\end{tabular}

Global Media Journal Mexico, Vol. 13, No. 25 Pp. 42-62. 


\begin{tabular}{|l|l|l|l|l|}
\hline YouTube & $0.0 \%$ & $0.0 \%$ & $46.4 \%$ & $61.5 \%$ \\
\hline Other & $17.6 \%$ & $12.30 \%$ & $3.6 \%$ & $9.6 \%$ \\
\hline
\end{tabular}

Next question: Do you share information about your school tasks using social networks? This impacts directly on collaboration, sharing information and papers using social networks. In this case, there is little use for BIM students - Always $=5.7 \%$ - in contrast to BBA students that have used it much more. It points out the fact that the last category "Never" decreased, which was over 20 and 30 percent in 2010 and has fallen to less than 15\% and 10\% in 2012 (see Table 5). It also highlights the drop in the category "Sometimes" for BIM's, from one year to the other.

TABLE 5. KNOWLEDGE SHARING COMPARISON AMONG SOCIAL MEDIA

\begin{tabular}{|l|l|l|l|l|}
\hline Answer Options & $\begin{array}{l}\text { BBA } \\
2010\end{array}$ & $\begin{array}{l}\text { BIM } \\
2010\end{array}$ & $\begin{array}{l}\text { BBA } \\
2012\end{array}$ & $\begin{array}{l}\text { BIM } \\
2012\end{array}$ \\
\hline MetroFLOG & $3.9 \%$ & $0.0 \%$ & $0.0 \%$ & $1.9 \%$ \\
\hline Hi5 & $7.8 \%$ & $3.2 \%$ & $0.0 \%$ & $1.9 \%$ \\
\hline Facebook & $78.4 \%$ & $81.0 \%$ & $96.6 \%$ & $90.4 \%$ \\
\hline Twitter & $7.8 \%$ & $22.2 \%$ & $24.1 \%$ & $30.8 \%$ \\
\hline MySpace & $3.9 \%$ & $0.0 \%$ & $3.4 \%$ & $0.0 \%$ \\
\hline Sonico & $0.0 \%$ & $0.0 \%$ & $3.4 \%$ & $1.9 \%$ \\
\hline Other & $17.6 \%$ & $19.0 \%$ & $10.3 \%$ & $13.5 \%$ \\
\hline
\end{tabular}

It is clear from the literature that students use these social networks for entertainment and information exchange - gossiping. We could think that they don't use it for academic purposes, but these data corroborates this statement since almost 20 percent of interviewed students use social networks to share school information.
The following question: Do you do your school tasks or school projects having any social network turned on in your computer? This seeks to verify the previous response to corroborate if social networks are turned on while working on school issues, which does not mean a continuous but alternating use or multi-task, as many young people do when they are working on the computer.

TABLE 6 INFORMATION SHARING ABOUT SCHOOL TASKS WITH SOCIAL MEDIA

\begin{tabular}{|l|l|l|l|l|}
\hline Answer Options & BBA & BIM & BBA & BIM \\
& 2010 & 2010 & 2012 & 2012 \\
\hline
\end{tabular}




\begin{tabular}{|l|l|l|l|l|}
\hline Always 100\% & $11.3 \%$ & $4.5 \%$ & $17.2 \%$ & $5.7 \%$ \\
\hline Not always 80\% & $17.0 \%$ & $23.9 \%$ & $10.3 \%$ & $22.6 \%$ \\
\hline Sometimes 60\% & $47.2 \%$ & $40.3 \%$ & $62.1 \%$ & $58.5 \%$ \\
\hline Never 0\% & $24.5 \%$ & $31.3 \%$ & $10.3 \%$ & $13.2 \%$ \\
\hline
\end{tabular}

It is clear that there is an increase in all cases, as shown in Table 6. In this sense, students stay connected at work, which means students can share information or data, request information and also have a moment of distraction.

TABLE 7. INFORMATION SHARING ABOUT SCHOOL TASKS WITH SOCIAL MEDIA

\begin{tabular}{|l|l|l|l|l|}
\hline Answer Options & BBA & BIM & BBA & BIM \\
2010 & 2010 & 2012 & 2012 \\
\hline Always 100\% & $25.0 \%$ & $16.2 \%$ & $34.5 \%$ & $23.5 \%$ \\
\hline Sometimes 80\% & $21.2 \%$ & $27.9 \%$ & $20.7 \%$ & $19.6 \%$ \\
\hline Depends on the job/school tasks 60\% & $46.2 \%$ & $41.2 \%$ & $41.4 \%$ & $49.0 \%$ \\
\hline Never 0\% & $7.7 \%$ & $14.7 \%$ & $3.4 \%$ & $7.8 \%$ \\
\hline
\end{tabular}

Next question: Have you ever explained any school tasks or activity using a social network? This question refers directly to knowledge transfer, not that much to the sharing of data or information. In this sense, we used the word "explain" as an important differentiator. Results speak for themselves. In 2010 this "explanation" slightly exceeded 20 percent of the cases which they did many times. But in 2012 this doubled, reaching $40 \%$ of the cases. At the same time, "explaining" dropped drastically face to face or on the phone in 2010 where it reached a $20 \%$ and fell less than $2 \%$ and $7 \%$ respectively in 2012 (see Table 7).

Another interesting finding is that BBA students "explained" in more occasions than BIM students.
Although it might seem contradictory, as expected, because of their nature that they would use social networks much more for their academic purposes.

Next question focuses on the resolution of specific questions rather than explaining processes. Data is consistent with the explanation and school tasks questions. BBA students use these tools more frequently than BIM students and growth in both is marginal between one measurement and the other. However, explaining face to face or using telephone drops drastically to zero in the case of BBA's and two percent in BIM's.

\section{TABLE 8. KNOWLEDGE TRANSFER AMONG STUDENTS?}




\begin{tabular}{|l|l|l|l|l|}
\hline Answer Options & BBA & BIM & BBA & BIM \\
& 2010 & 2010 & 2012 & 2012 \\
\hline Many times & $15.1 \%$ & $20.9 \%$ & $41.4 \%$ & $39.6 \%$ \\
\hline I have sometimes explained & $35.8 \%$ & $28.4 \%$ & $27.6 \%$ & $37.7 \%$ \\
\hline I have explained a few times & $30.2 \%$ & $23.9 \%$ & $24.1 \%$ & $20.8 \%$ \\
\hline I have never explained, I explain face to face or per phone & $18.9 \%$ & $26.9 \%$ & $6.9 \%$ & $1.9 \%$ \\
\hline
\end{tabular}

The following question in our survey was: Have you been able to solve doubts with the help from a friend using any of the social networks? We were trying to understand the preferences or the usefulness of social networks for both aspects: final projects and school tasks. In this sense, surveyed students have increased their interest, according to the data of both measurements (see Table 9). This option helped very much. It grew up to $10 \%$ for BBA students and $8 \%$ for BIM students. The option "No help at all" fell 14\% for BIM's and $3.8 \%$ for BBA students reaching " $0 \%$ " in 2012.

TABLE 9. EXPLAINING CONCEPTS THROUGH SOCIAL MEDIA

\begin{tabular}{|l|l|l|l|l|}
\hline Answer Options & BBA 2010 & BIM 2010 & BBA 2012 & BIM 2012 \\
\hline Many times & $26.4 \%$ & $22.1 \%$ & $28.6 \%$ & $24.5 \%$ \\
\hline I have sometimes explained & $35.8 \%$ & $30.9 \%$ & $53.6 \%$ & $52.8 \%$ \\
\hline I have explained a few times & $24.5 \%$ & $36.8 \%$ & $17.9 \%$ & $20.8 \%$ \\
\hline I have never explained, I explain face to face or per phone & $13.2 \%$ & $10.3 \%$ & $0.0 \%$ & $1.9 \%$ \\
\hline
\end{tabular}

students who increased almost $8 \%$ their preference to

The following question was: Have social networks been useful regarding your school tasks and/or projects? This question focused on the use of specialized tasks such as final papers or projects, not common homework. The previous ones focused on daily work, school tasks, reading, etc. In this case, a slight increase in the variable: "All my papers and projects" can also be observed for both types of students. But it also emphasizes the continuity of the response in the type of project - third variable - where BIM students have a slight variation compared to BBA use social networks (see Table 10).

Findings of this descriptive research show that the use and expectations of social networks have increased in the case of surveyed college students in 2010 and 2012. These social networks - Twitter and Facebook are used to communicate, to share information, to explain concepts and to answer questions about school/college aspects. While data in this survey are merely exploratory, we need to search much more about each of these cognitive aspects. It is clear that these digital natives have migrated to these platforms 
TABLE 10. KNOWLEDGE TRANSFER AMONG

\begin{tabular}{|l|l|l|l|l|}
\hline Answer Options & $\begin{array}{l}\text { BBA } \\
2010\end{array}$ & $\begin{array}{l}\text { BIM } \\
2010\end{array}$ & $\begin{array}{l}\text { BBA } \\
2012\end{array}$ & $\begin{array}{l}\text { BIM } \\
2012\end{array}$ \\
\hline Helped very much & $17.0 \%$ & $16.2 \%$ & $27.6 \%$ & $24.5 \%$ \\
\hline Some help & $50.9 \%$ & $47.1 \%$ & $44.8 \%$ & $52.8 \%$ \\
\hline Little help & $28.3 \%$ & $23.5 \%$ & $27.6 \%$ & $22.6 \%$ \\
\hline No help at all & $3.8 \%$ & $13.2 \%$ & $0.0 \%$ & $0.0 \%$ \\
\hline
\end{tabular}

TABLE 10. Social MEdia USE ON PROJECTS OR FinAl PAPERS

\begin{tabular}{|l|l|l|l|l|}
\hline Answer Options & BBA & BIM & BBA & BIM \\
2010 & 2010 & 2012 & 2012 \\
\hline All my papers and projects (100\%) & $3.8 \%$ & $3.2 \%$ & $6.9 \%$ & $5.7 \%$ \\
\hline Some of my papers and projects (80\%) & $23.1 \%$ & $17.7 \%$ & $17.2 \%$ & $18.9 \%$ \\
\hline Depends on the paper/school tasks (50\%) & $30.8 \%$ & $29.0 \%$ & $37.9 \%$ & $30.2 \%$ \\
\hline
\end{tabular}

$13.24 \%$ of BBA's students and $3.77 \%$ of BIM's students of the sample of 2010 believed that social networks didn't help in projects and homework. But not a single student in the sample of 2012 thinks that social networks aren't useful for their academic activities.

\section{Conclusions}

The objective of this research is to answer the question: How do college students use social networks to improve communication and exchange knowledge? We analyzed online social networks in which they are connected while doing their schoolwork. We also analyzed the use of the words "explanation" or "resolution of doubts" as categories for the analysis in order to determine the exchange of information. We Global Media Journal Mexico, Vol. 13, No. 25 Pp. 42-62. also got to know their "preferences or usefulness" of networks at the time of doing their school work.

Likewise, we observed that the explanation of concepts, data sharing and the fulfillment of school works or final projects increased using these social networks. These evidence supports previous research (Merril, 2011; Koroleva, et.al (2011), and more recent research as the findings of Saw et al. (2013).

We found out that the use of social network platforms such as Twitter and Facebook have increased for business administration and informatics management students, displacing similar platforms. 
The migration of social networks from MetroFLOG and Hi5 to Twitter, YouTube and mainly Facebook is notable for 2012. It would be important to apply this study nowadays in order to find new trends in the use of social networks as well as to study Twitter, Facebook and YouTube as different phenomena.

Paradoxically, we also found out that surveyed business administration students use these platforms even more than informatics management students. It would seem that because of their professional orientation, informatics management students would use these social networks even more. We also concluded that informatics' students prefer to use Twitter more than the business' ones.

In general, the increased use of social networks is remarkable and students find the use of social media platforms more useful to help and support in tasks related to school projects and homework. It also improves "communication" and knowledge sharing which is supported by some scholars such as Junco, Elavsky \& Heibergerg (2012) and Lampe \& Ellison (2007). Also our research provides enough evidence to support the idea of this connective knowledge (Molnar $\&$ Szuts, 2014) that is increasing nowadays.

More research needs to be done in this field in order to be able to determine the useful effectiveness of social networks in academic activities or if they are just distractors. This research will become a first contribution to the study of social networks in Mexican universities, as well as a tool for understanding the use of these technologies among students of different generations.

The sample size and gender are limitations on this research because we couldn't collect all of the total data we expected. Another limitation is that we didn't classify the two samples into males and females. Only for the year 2012 we got a $51.72 \%$ of males and $48.28 \%$ of females for business' students, and $52.83 \%$ of males and 47.17 of females for informatics' students. It will be important to study each gender in future works in order to make assumptions about males and females. Another limitation is the descriptive focus of the research. In a further research we will use variables to prove some kind of correlation or causality.

Due to the increase of followers of Facebook, it is important to focus on some specific research in the use of this social media tool and schoolwork, students' collaboration and information exchange. Also research on Twitter, YouTube, and other social media in education - Skype, WhatsApp - could provide different insights about this new impact of technology in college students' education.

\section{References}

Aharony, N. (2012). Facebook use in libraries: an exploratory analysis. Aslib Proceedings, 64(4), 358-372. http://doi.org/10.1108/00012531211244725 
Aharony, N. (2013). Facebook use by Library and Information Science students. Aslib Proceedings, 65(1), 19-39. http://doi.org/10.1108/00012531311297168

Ahn, J. (2011). Teenagers and social network sites: Do off-line inequalities predict their online social networks? First Monday, 17(1). Retrieved from http://firstmonday.org/ojs/index.php/fm/article/view/3752

Ahn, M. J. (2011). Adoption of E-Communication Applications in US Municipalities: The Role of Political Environment, Bureaucratic Structure, and the Nature of Applications. American Review of Public Administration, 41, 428-452. JOUR. http://doi.org/Doi 10.1177/0275074010377654

AMIPCI. (2012). AMIPCI - Hábitos de Internet. Retrieved from http://www.amipci.org.mx/?P=esthabitos

AMIPCI. (2014). Hábitos de Usuarios de Internet en México. Retrieved from www.amipci.com.mx

Au, M., Lam, J., \& Chan, R. (2014). Social Media Education: Barriers and Critical Issues (Vol. 494, pp. 199-205). Springer Berlin Heidelberg. Retrieved from http://link.springer.com/chapter/10.1007/978-3-662-46158-7_20

Bauerlein, M. (2009). The dumbest generation: how the digital age stupefies young Americans and jeopardizes our future : or, Don't trust anyone under 30. New York, NY: Jeremy P. Tarcher/Penguin. Retrieved from http://www.amazon.com/The-Dumbest-Generation-StupefiesJeopardizes/dp/1585427128/ref=wl_mb_hu_m_1_dp

Bauerlein, M. (2011). The digital divide arguments for and against Facebook, Google, texting, and the age of social networking. New York: Jeremy P. Tarcher/Penguin. Retrieved from http://www.contentreserve.com/TitleInfo.asp?ID=\{E4F5A50E-1CBD-4D7E-A3B148BB1335FA43 $\}$ \&Format $=50$

Boyd, D., \& Hargittai, E. (2010). Facebook privacy settings: Who cares? First Monday, 15(2). Retrieved from http://firstmonday.org/htbin/cgiwrap/bin/ojs/index.php/fm/article/view/3086/2589

Burkell, J., Fortier, A., Wong, L. (Lola) Y. C., \& Simpson, J. L. (2014). Facebook: public space, or private space? Information, Communication \& Society, O(0), 1-12. JOUR. http://doi.org/10.1080/1369118X.2013.870591

Celik, I., \& Schoreels, C. (2014). Use of Social Media across Different Generations in Higher Education in a Developing Country. In C. Rensing, S. de Freitas, T. Ley, \& P. J. Muñoz-Merino (Eds.), Open Learning and Teaching in Educational Communities (pp. 42-55). Springer International Publishing.

Chung, K. S. K., \& Chatfield, A. T. (2011). An empirical analysis of Online Social Network structure to understand Global Media Journal Mexico, Vol. 13, No. 25 Pp. 42-62. 
\begin{tabular}{c|r} 
Sandoval-Almazan, Valle-Cruz & 59 \\
Online Activities through Social Media by High Education Students
\end{tabular}

citizen engagement in public policy and community building. International Journal of Electronic Governance, 4 , 85-103. JOUR. Retrieved from

http://www.inderscience.com/search/index.php?action=record\&rec_id=41709\&prevQuery=\&ps=10\&m=or

Cruz, A. (2011, November). El Universal - - La telefonía móvil sigue al alza en México. El Universal. Gran diario de Mexico. Mexico. Retrieved from http://www.eluniversal.com.mx/finanzas/91029.html

Danino, N., \& Sim, G. (2014). TReACLE: A framework for TwitteR Analysis in a SoCial and Learning Environment (pp. 293-298). ACM Digital Library. Retrieved from http://dl.acm.org/citation.cfm?id=2742941.2742983

Di Valentin, C., Emrich, A., Lahann, J., Schmidt, M., Schwertel, U., Weth, D., \& Loos, P. (2014). Adaptive recommendations to foster social media skills in teaching and learning scenarios. New York, USA: ACM Digital Library. http://doi.org/10.1145/2637748.2638434

Ellison, N. B., Steinfield, C., \& Lampe, C. (2007). The Benefits of Facebook "Friends:" Social Capital and College Students' Use of Online Social Network Sites. Journal of Computer-Mediated Communication, 12(4), 11431168. http://doi.org/10.1111/j.1083-6101.2007.00367.x

Estalella, A., \& Ardevol, E. (2011). e-research: challenges and opportunities for social sciences. Convergencia Revista de Ciencias Sociales, 18(55), 87-111.

Fardoun, H. M., Zafar, B., \& Ciprés, A. P. (2013). Using facebook for collaborative academic activities in education (pp. 137-146). Berlin, Heidelberg: Springer-Verlag. http://doi.org/10.1007/978-3-642-39371-6_16

Freeman, R. J. (2004). The Los Angeles County Experience: A Field Study of Information Technology Issues Challenging Local Government. Journal of E-Government, 1, 93-101. JOUR. Retrieved from http://www.haworthpress.com/store/Toc_views.asp?sid=DPQGRJK1VR7S8G1R8F60PBJ2XN0V9NF9\&TOCN ame $=\mathrm{J} 399 \mathrm{v} 01 \mathrm{n} 02 \% 5 \mathrm{FTOC} \&$ desc $=$ Volume $\% 3 \mathrm{~A} 1$ Issue $\% 3 \mathrm{~A} 2$

Gallupe, R. B. (2007). The Tyranny of Methodologies in Information Systems Research 1. Data Base For Advances In Information Systems, 38(3), 20-28. http://doi.org/10.1145/1278253.1278258

Greenhow, C. (2011). Online social networks and learning. On the Horizon, 19(1), 4-12. http://doi.org/10.1108/10748121111107663

Hargittai, E. (2007). Whose Space? Differences Among Users and Non-Users of Social Network Sites. ComputerMediated Comunication, 13(1). Journal Article. Retrieved from http://jcmc.indiana.edu/vol13/issue1/hargittai.html

Global Media Journal Mexico, Vol. 13, No. 25 Pp. 42-62. 
\begin{tabular}{c|c} 
Sandoval-Almazan, Valle-Cruz & 60 \\
Online Activities through Social Media by High Education Students
\end{tabular}

Haythornthwaite, C. (2005). Social networks and Internet connectivity effects. Information, Communication \& Society, 8(2), 125-147. http://doi.org/10.1080/13691180500146185

Hernández Sampieri, R., Fernandez Collado, C., \& Baptista Lucio, P. (2010). Metodologia de la Investigacion (5th ed., Vol. 1). BOOK, Mexico: McGraw-Hill.

Indrupati, J., \& Henari, T. (2012). Entrepreneurial success, using online social networking: evaluation. Education, Business and Society: Contemporary Middle Eastern Issues, 5(1), 47-62.

http://doi.org/10.1108/17537981211225853

INEGI. (2011). Mexico un País de Jovenes. Mexico. Retrieved from

http://www.inegi.org.mx/inegi/contenidos/espanol/prensa/contenidos/Articulos/sociodemograficas/mexicojovenes.pdf

Isacsson, A., \& Gretzel, U. (2011). Facebook as an edutainment medium to engage students in sustainability and tourism. Journal of Hospitality and Tourism Technology, 2(1), 81-90.

http://doi.org/10.1108/17579881111112430

Jessen, J., \& Jørgensen, A. H. (2011). Aggregated trustworthiness: Redefining online credibility through social validation. First Monday, 17(1). Retrieved from http://firstmonday.org/ojs/index.php/fm/article/view/3731

Kamal, N., Fels, S., Fergusson, M., Preece, J., Cosley, D., \& Munson, S. (2013). Designing social media for change (pp. 3183-3186). New York, USA: ACM Digital Library. http://doi.org/10.1145/2468356.2479642

Katz, N., Lazer, D., Arrow, H., \& Contractor, N. (2004). Network Theory and Small Groups. Small Group Research, 35(3), 307-332. http://doi.org/10.1177/1046496404264941

Kavanaugh, A., Zin, T. T., Caroll, J. M., Schmitz, J., Pérez-Quiñoles, M., \& Isenhour, P. (2006). When Opinion Leaers Blog: New forms of citizen interaction. In 7th Annual Internacional Conference on Digita Government Research (pp. 79-89). http://doi.org/10.1007/s13398-014-0173-7.2

Kilpeläinen, A., Päykkönen, K., \& Sankala, J. (2011). The Use of Social Media to Improve Social Work Education in Remote Areas. Journal of Technology in Human Services, 29(1), 1-12. http://doi.org/10.1080/15228835.2011.572609

Koles, B., \& Nagy, P. (2012). Facebook usage patterns and school attitudes. Multicultural Education \& Technology Journal, 6(1), 4-17. http://doi.org/10.1108/17504971211216283 
Koroleva, K., Brecht, F., Goebel, L., \& Malinova, M. (2011). Generation Facebook - A cognitive calculus model of teenage user behavior on Social Network sites. BOOK, AISnet.

Krishnamurthy, B., \& Wills, C. E. (2008). Characterizing privacy in online social networks. Generic, Seattle, WA, USA: ACM.

Lampe, C., Ellison, N., \& Steinfield, C. (2006). A face(book) in the crowd: social Searching vs. social browsing. BOOK, ACM.

Lenartz, A. J. (2012). Establishing Guidelines for the Use of Social Media in Higher Education (pp. 333-353). Emerald Group Publishing Limited. Retrieved from http://www.emeraldinsight.com/doi/abs/10.1108/S2044$9968 \% 282012 \% 290000005018$

Loving, M., \& Ochoa, M. (2011). Facebook as a classroom management solution. New Library World, 112(3/4), 121130. http://doi.org/10.1108/03074801111117023

Marwick, A. E., \& boyd, D. (2014). Networked privacy: How teenagers negotiate context in social media. New Media \& Society, 1461444814543995. http://doi.org/10.1177/1461444814543995

Molnar, G., \& Szuts, Z. (2014). Advanced mobile communication and media devices and applications in the base of higher education (pp. 169-174). IEEE. http://doi.org/10.1109/SISY.2014.6923580

Murthy, D. (2013). Ethnographic Research 2.0: The potentialities of emergent digital technologies for qualitative organizational research. Journal of Organizational Ethnography, 2(1), 23-36. http://doi.org/10.1108/JOE-012012-0008

Nicholas Carr. (2011). ¿Qué está haciendo internet con nuestras mentes? Superficiales (Primera ed, Vol. 1). Mexico: W.W. Norton.

Nicolle Merrill. (2011). Social media for social research: Applications for higher education communications (1st ed., Vol. 2, pp. 25-48). Emerald Group Publishing Limited. Retrieved from 10.1108/S2044-9968(2011)0000002005

Nirban, V. S., \& Chasul. (2014). Learning management system acceptance behaviour of students in higher education (pp. 108-111). IEEE. http://doi.org/10.1109/MITE.2014.7020251

Oboler, A. (2008). The rise and fall of a Facebook hate group. First Monday, 13(11). Retrieved from http://firstmonday.org/htbin/cgiwrap/bin/ojs/index.php/fm/article/view/2254/2048 
Pinho, J. C. M. R., \& Soares, A. M. (2011). Examining the technology acceptance model in the adoption of social networks. Journal of Research in Interactive Marketing, 5(2/3), 116-129.

http://doi.org/10.1108/17505931111187767

Rajagopal, K., Brinke, D. J., Bruggen, J. Van, \& Sloep, P. B. (2011). Understanding personal learning networks: Their structure, content and the networking skills needed to optimally use them. First Monday, 17(1). Retrieved from http://firstmonday.org/ojs/index.php/fm/article/view/3559

Richardson, K., \& Hessey, S. (2009). Archiving the self? Facebook as biography of social and relational memory. Journal of Information, Communication and Ethics in Society, 7(1), 25-38. http://doi.org/10.1108/14779960910938070

Ruleman, A. B. (2012). Social media at the university: a demographic comparison. New Library World, 113(7/8), 316-332. http://doi.org/10.1108/03074801211244940

Saw, G., Abbott, W., Donaghey, J., \& McDonald, C. (2013). Social media for international students - it's not all about Facebook. Library Management, 34(3), 156-174. http://doi.org/10.1108/01435121311310860

Swamynathan, G., Wilson, C., Boe, B., Almeroth, K., \& Zhao, B. Y. (2008). Do social networks improve ecommerce?: a study on social marketplaces. Generic, Seattle, WA, USA: ACM.

Tapscott, D. (2009). Grown up digital: how the net generation is changing your world. New York: McGraw-Hill. Retrieved from http://www.amazon.com/books/dp/0071508635

Teoh, K.-K., Pourshafie, T., \& Balakrishnan, V. (2014). A gender lens perspective of the use of social network in higher education in Malaysia and Australia (p. 21). Beijing, China: ACM Digital Library. Retrieved from http://dl.acm.org/citation.cfm?doid=2639968.2640070

Theocharis, Y. (2012). Cuts, Tweets, Solidarity and Mobilisation: How the Internet Shaped the Student Occupations. Parliamentary Affairs, 65, 162-194. JOUR. http://doi.org/10.1093/Pa/Gsr049

Tuten, T., Wetsch, L., \& Munoz, C. (2015). Conversation Beyond the Classroom: Social Media and Marketing Education (pp. 317-317). Springer International Publishing. Retrieved from http://link.springer.com/chapter/10.1007/978-3-319-11797-3_182\#

Wang, Y., Niiya, M., Mark, G., Reich, S. M., \& Warschauer, M. (2015). Coming of Age (Digitally): An Ecological View of Social Media Use among College Students (pp. 571-582). New York, USA: ACM Digital Library. http://doi.org/10.1145/2675133.2675271

Global Media Journal Mexico, Vol. 13, No. 25 Pp. 42-62. 